\title{
Allylic Proton-Proton Coupling in Stereodefined Alkylidenecyclobutanes and Alkylidenecycopentanes
}

\author{
William F. Bailey ${ }^{1 *}$ and Timo V. Ovaska ${ }^{2 *}$ \\ ${ }^{1}$ Department of Chemistry, The University of Connecticut, Storrs, Connecticut 06269-3060, USA. \\ William.Bailey@uconn.edu \\ 2 Department of Chemistry, Connecticut College, New London, Connecticut 06320-4196, USA. tvova@conncoll.edu
}

Dedicated to Professor Ernest L. Eliel: a giant in the field of stereochemistry and to us a mentor and friend to whom much is owed for his generous support and encouragement.

Received June 28, 2009; accepted August 14, 2009

\begin{abstract}
Analysis of the ${ }^{1} \mathrm{H}$ NMR spectra of eight stereodefined alkylidenecycloalkanes allows determination of the magnitude of allylic coupling in these compounds. In contrast to the trend normally observed, the magnitude of transoid-allylic coupling was found to be invariably greater by $\sim 0.5 \mathrm{~Hz}$ than the cisoid-allylic coupling. The larger transoid-allylic coupling may be attributed to the slightly smaller dihedral angle relating allylic $=\mathrm{C}-\mathrm{C}-\mathrm{H}$ plane with the $\mathrm{C}=\mathrm{C}-\mathrm{C}$ plane in the $E$-isomers.

Keywords: Proton NMR, Allylic Coupling, Alkylidenecycloalkanes
\end{abstract}

\section{Introduction}

Some time ago we reported, as illustrated below, that acetylenic alkyllithiums, generated in quantitative yield by low-temperature lithium-iodine exchange between an acetylenic alkyl iodide and tert-butyllithium $(t-\mathrm{BuLi})$, undergo regiospecific exo-dig cyclization to give 4-, 5-, or 6-membered rings on warming $[1,2]$. In the course of this work, eight isomerically pure alkylidenecycloalkanes, illustrated in Figure 1, bearing gem-dimethyl groups at the endocyclic allylic position were prepared and characterized [2]. It occurred to us that these compounds presented an opportunity to investigate the magnitude of the ${ }^{4} \mathrm{~J}{ }^{1} \mathrm{H}-{ }^{1} \mathrm{H}$ allylic coupling in a series of fairly rigid, stereodefined systems that display first-order behavior.
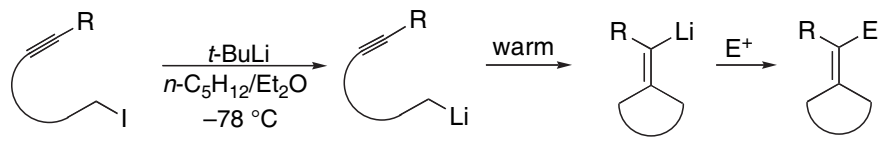

An extensive literature dealing with allylic ${ }^{1} \mathrm{H}-{ }^{1} \mathrm{H}$ coupling has accumulated since the pioneering studies by Barfield [3], Karplus [4], Sternhell [5], McConnell [6] and others and the experimental data, as well as theoretical treatments, have been thoroughly reviewed [7]. The allylic coupling is typically of negative sign [7] and magnitude of the allylic coupling is related, as illustrated below, to the dihedral angle $(\Phi)$ between the allylic $\mathrm{C}-\mathrm{H}_{\mathrm{X}}$ bond and the plane of the $\pi$-orbitals that
Resumen. El análisis de los espectros de RMN protónica de ocho alquilidéncicloalcanos estereoisoméricos permite determinar la magnitud de los acoplamientos alílicos en estos compuestos. En contraste con la tendencia normal, la magnitud de los acoplamientos en segmentos alílicos transoides es siempre mayor que la encontrada en sistemas alílicos cisoides, por aproximadamente $0.5 \mathrm{~Hz}$. Los valores mas grandes en las constantes de acoplamiento para los sistemas transoides pudiera explicarse con base en el ángulo diedro existente entre el plano alílico $=\mathrm{C}-\mathrm{C}-\mathrm{H}$ y el plano en el segmento $\mathrm{C}=\mathrm{C}-\mathrm{C}$ presente en los isómeros $E$, que es ligeramente mas pequeño.

Keywords: RMN de protones, acoplamientos alílicos, alquilidéncicloalcanos.

constitute the $\pi$-bond (viz., the bisector of the $\mathrm{C}_{\mathrm{vinyl}}-\mathrm{C}_{\mathrm{X}}-\mathrm{H}_{\mathrm{X}}$ angle): the maximum value for ${ }^{4} \mathrm{~J}_{\text {allyl }}$ will result when $\Phi$ is $0^{\circ}$ because the $\mathrm{C}-\mathrm{H}$ bond and the $\pi$-orbital are then coplanar $[3$, 7]. It might be noted that this definition of $\Phi$, which follows the convention introduced by Barfield in his pioneering treatment of allylic coupling [3], differs from that used in more recent discussions in which the angle between the allylic $\mathrm{C}-\mathrm{H}$ bond and the plane of the three carbon unit is taken as $\Phi$ [7]. Clearly, by this later definition of the dihedral angle, the maximum value for ${ }^{4} \mathrm{~J}_{\text {allyl }}$ results when $\Phi$ is $90^{\circ}$ [7].

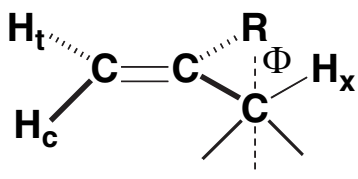

Two modes of coupling may be distinguished: a transoid coupling, ${ }^{4} \mathrm{~J}_{\text {trans }}$, between $\mathrm{H}_{\mathrm{X}}$ and $\mathrm{H}_{\mathrm{t}}$ and a cisoid coupling, ${ }^{4} \mathrm{~J}_{\text {cis }}$, between $\mathrm{H}_{\mathrm{X}}$ and $\mathrm{H}_{\mathrm{c}}$. While there are a good deal of ${ }^{4} \mathrm{~J}_{\text {trans }}$ data in the literature, there are relatively few experimental values for ${ }^{4} \mathrm{~J}_{\text {cis }}$ coupling in stereodefined systems [7, 8]. It has been noted, however, that the magnitude of the cisoid coupling is generally greater than the transoid coupling in a given system $[7,8]$. In contrast to this trend, as detailed below, the allylic coupling constants of all of the compounds investigated in this study (Figure 1) have ${ }^{4} J_{\text {trans }}>{ }^{4} J_{\text {cis }}$ and the magnitude of the couplings are related to the dihedral angle, $\Phi$. 


\section{Results and Discussion}

Examination of the proton NMR spectra of the eight stereodefined alkylidenecycloalkanes, which are summarized in Tables 1 and 2, reveals some interesting trends. The chemical shifts of the vinyl proton in both phenyl-substituted (1 and $\mathbf{3})$ and trimethylsilyl-substituted ( 2 and 4,) Z-cycloalkylidenes are consistently downfield, by $0.03-0.25 \mathrm{ppm}$, in comparison to the analogous chemical shifts of the E-isomers. The gem-dimethyl protons in the Z-trimethylsilyl-substituted cyclobutylidene (Z-4) and cyclopentylidene (Z-2) compounds appear downfield by $0.11-0.12 \mathrm{ppm}$ compared to those of the E-isomers (E-4 and E-2, respectively). In the aromatic series, the methyl protons of both cyclobutylidene isomers, E-3 and Z-3, have very similar proton chemical shifts (viz., $\delta=1.25$ and 1.29, respectively). However, the methyl protons of Z-benzylidenecyclopentane (Z-1) resonate upfield by $0.15 \mathrm{ppm}$ compared to those of the isomeric E-compound (E-1). This observation is in accord with the geometry of the calculated minimum energy conformation (vide infra) of Z-benzylidenecyclopentane (Z1) which suggests that the phenyl ring lies at a $\sim 80^{\circ}$ angle to the plane of the double bond: the methyl protons are therefore expected to be somewhat shielded by the ring current of the aromatic ring. The calculated distance (vide infra) between the methyl protons and the phenyl ring is greater in $\mathrm{Z}$ - ben-<smiles>CC1(C)CCCC1=Cc1ccccc1</smiles>
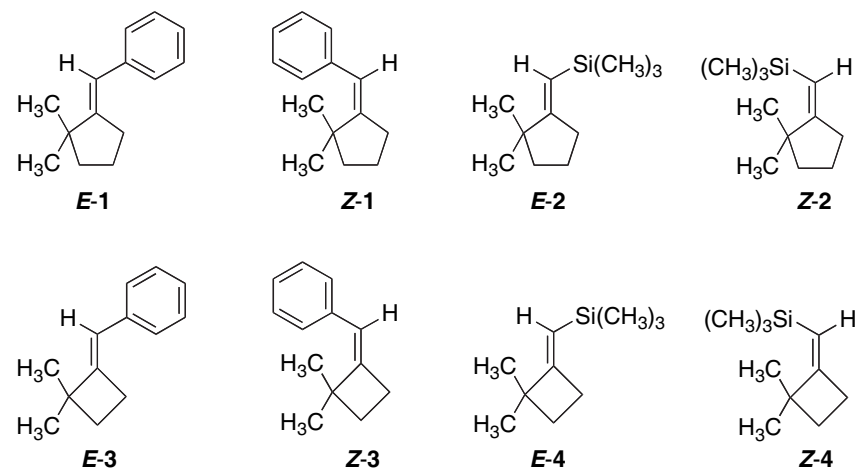

Fig. 1. Stereodefined Alkylidenecycloalkanes

zylidenecyclobutane (Z-3) than in $\mathbf{Z - 1}$ and for this reason the effect of the diamagnetic anisotropy exhibited by the phenyl ring is expected to be less important in the cyclobutane compound.

Examination of the allylic coupling constants of all of the compounds studied (Tables 1 and 2) clearly shows that the magnitude of ${ }^{4} \mathrm{~J}_{\text {trans }}$ is invariably greater by $\sim 0.5 \mathrm{~Hz}$ than is the magnitude of ${ }^{4} \mathrm{~J}_{\text {cis }}$. As noted above, the opposite trend is generally observed $[7,8]$. Indeed, we had initially relied on the relative magnitudes of the allylic couplings to assign the

Table 1. Proton NMR Data for Benzylidenecycloalkanes ${ }^{\mathrm{a}}$

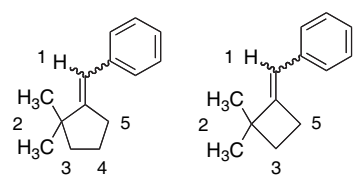

\begin{tabular}{|c|c|c|c|c|c|c|}
\hline Z-1 & $\begin{array}{c}6.42 \\
\text { broad s }\end{array}$ & $\begin{array}{c}1.00 \\
\mathrm{~s}\end{array}$ & $\begin{array}{c}1.55 \\
\mathrm{t}, \mathrm{J}=6.89 \mathrm{~Hz}\end{array}$ & $\begin{array}{c}1.61-1.69 \\
\mathrm{~m}\end{array}$ & $\begin{array}{c}2.55 \\
\mathrm{t} \text { of doublets } \\
{ }^{3} \mathrm{~J}=7.37 \mathrm{~Hz} \\
{ }^{4} \mathrm{~J}=2.07 \mathrm{~Hz}\end{array}$ & $\begin{array}{c}7.16-7.31 \\
\mathrm{~m}\end{array}$ \\
\hline E-1 & $\begin{array}{c}6.17 \\
\mathrm{t}, \mathrm{J}=2.56 \mathrm{~Hz}\end{array}$ & $\begin{array}{c}1.15 \\
\mathrm{~s}\end{array}$ & $\begin{array}{c}1.55 \\
\mathrm{t}, \mathrm{J}=6.86 \mathrm{~Hz}\end{array}$ & $\begin{array}{c}1.74 \\
\text { app. quintet } \\
\mathrm{J}=7.06 \mathrm{~Hz}\end{array}$ & $\begin{array}{c}2.67 \\
\mathrm{t} \text { of doublets } \\
{ }^{3} \mathrm{~J}=7.25 \mathrm{~Hz} \\
{ }^{4} \mathrm{~J}=2.56 \mathrm{~Hz}\end{array}$ & $\begin{array}{c}7.15-7.31 \\
\mathrm{~m}\end{array}$ \\
\hline Z-3 & $\begin{array}{c}6.10 \\
\mathrm{t}, \mathrm{J}=2.15 \mathrm{~Hz}\end{array}$ & $\begin{array}{c}1.29 \\
\mathrm{~s}\end{array}$ & $\begin{array}{c}1.78 \\
\mathrm{t}, \mathrm{J}=8.04 \mathrm{~Hz}\end{array}$ & & $\begin{array}{c}2.69 \\
\mathrm{t} \text { of doublets } \\
{ }^{3} \mathrm{~J}=8.03 \mathrm{~Hz} \\
{ }^{4} \mathrm{~J}=2.15 \mathrm{~Hz}\end{array}$ & $\begin{array}{c}7.14-7.30 \\
\mathrm{~m}\end{array}$ \\
\hline
\end{tabular}

${ }^{\text {a }}$ Recorded in $\mathrm{CDCl}_{3}$; numbers on structures refer to the tabulated proton chemical shifts. The sign of the coupling constants were not determined. 
Table 2. Proton NMR Data for TMS-Substituted Cycloalkylidenes ${ }^{\mathrm{a}}$

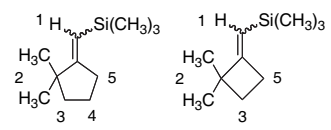

\begin{tabular}{|c|c|c|c|c|c|c|}
\hline Z-2 & $\begin{array}{c}5.27 \\
\mathrm{t}, \mathrm{J}=2.05 \mathrm{~Hz}\end{array}$ & $\begin{array}{c}1.11 \\
\mathrm{~s}\end{array}$ & $\begin{array}{c}1.55 \\
\mathrm{t}, \mathrm{J}=7.80 \mathrm{~Hz}\end{array}$ & $\begin{array}{c}1.56-1.61 \\
\mathrm{~m}\end{array}$ & $\begin{array}{c}2.48 \\
\mathrm{t} \text { of doublets } \\
{ }^{3} \mathrm{~J}=7.79 \mathrm{~Hz} \\
{ }^{4} \mathrm{~J}=2.05 \mathrm{~Hz}\end{array}$ & $\begin{array}{c}0.08 \\
\mathrm{~s}\end{array}$ \\
\hline E-2 & $\begin{array}{c}5.18 \\
\mathrm{t}, \mathrm{J}=2.34 \mathrm{~Hz}\end{array}$ & $\begin{array}{c}0.99 \\
\mathrm{~s}\end{array}$ & $\begin{array}{c}1.48 \\
\mathrm{t}, \mathrm{J}=6.38 \mathrm{~Hz}\end{array}$ & $\begin{array}{c}1.63 \\
\text { app. quintet } \\
\mathrm{J}=7.07 \mathrm{~Hz}\end{array}$ & $\begin{array}{c}2.39 \\
\mathrm{t} \text { of doublets } \\
{ }^{3} \mathrm{~J}=7.31 \mathrm{~Hz} \\
{ }^{4} \mathrm{~J}=2.34 \mathrm{~Hz}\end{array}$ & $\begin{array}{c}0.06 \\
\mathrm{~s}\end{array}$ \\
\hline $\mathrm{Z}-4$ & $\begin{array}{c}5.09 \\
\mathrm{t}, \mathrm{J}=2.09 \mathrm{~Hz}\end{array}$ & $\begin{array}{c}1.19 \\
\mathrm{~s}\end{array}$ & $\begin{array}{c}1.66 \\
\mathrm{t}, \mathrm{J}=8.09 \mathrm{~Hz}\end{array}$ & & $\begin{array}{c}2.57 \\
\mathrm{t} \text { of doublets } \\
{ }^{4} \mathrm{~J}=2.09 \mathrm{~Hz}\end{array}$ & $\begin{array}{c}0.08 \\
\mathrm{~s} \\
{ }^{3} \mathrm{~J}=8.09 \mathrm{~Hz}\end{array}$ \\
\hline
\end{tabular}

${ }^{\text {a }}$ Recorded in $\mathrm{CDCl}_{3}$; numbers on structures refer to the tabulated proton chemical shifts. The sign of the coupling constants were not determined.

stereochemistry of the gem-dimethyl alkylidenecycloalkanes; however, detailed NOE-difference spectra and phase-sensitive NOESY experiments, as well as single-crystal X-ray analysis of a derivatized product, confirmed the assignments illustrated in Figure 1 [2]. In an effort to rationalize the observation that the transoid allylic coupling in the E-isomers is larger than the cisoid coupling in the corresponding Z-isomers, the dihedral angle $(\Phi)$ between the allylic $\mathrm{C}-\mathrm{C}-\mathrm{H}$ unit and the plane of the $\pi$-orbital in each compound were estimated from the minimum energy structure of each isomer obtained using the MM2parameter set [9] incorporated into the Chem3D Pro program

Table 3. Correlation of the Magnitude of Allylic Coupling Constants of Alkylidenecycloalkanes (Fig. 1) to Calculated F Values

\begin{tabular}{cccc}
\hline entry & compound & F, ${ }^{\circ}$ & ${ }^{4} \mathrm{~J}, \mathrm{~Hz}$ \\
\hline 1 & $\mathbf{Z - 3}$ & 39.8 & 2.15 \\
2 & $\mathbf{E - 3}$ & 39.0 & 2.60 \\
3 & $\mathbf{Z - 4}$ & 40.0 & 2.09 \\
4 & $\mathbf{E - 4}$ & 33.4 & 2.57 \\
5 & $\mathbf{Z}-1$ & 25.1 & 2.07 \\
6 & $\mathbf{E - 1}$ & 24.0 & 2.56 \\
7 & $\mathbf{Z - 2}$ & 13.6 & 2.05 \\
8 & $\mathbf{E - 2}$ & 10.5 & 2.34 \\
\hline
\end{tabular}

[10]. It might be noted, as detailed elsewhere [2], that the Xray structure of a crystalline derivative of $\mathbf{Z}-\mathbf{1}$ is virtually identical to that computed by molecular mechanics using the MM2 parameters. The results of these calculations are summarized in Table 3.

Inspection of the data presented in Table 3 reveals that, for a given set of isomers, the larger allylic coupling, ${ }^{4} \mathrm{~J}_{\text {trans }}$, is found in the E-isomer and this in turn is the isomer with the smaller value of $\Phi$. Hence, the magnitude of the ${ }^{4} \mathrm{~J}_{\text {trans }}$ coupling is larger than that of the ${ }^{4} \mathrm{~J}_{\text {cis }}$ coupling as a result of a more effective overlap of the orbitals in the allylic $\mathrm{C}-\mathrm{H}$ bond with the $\pi$-system in the E-isomers.

\section{Acknowledgment}

This work was supported by the Connecticut Department of Economic Development. We thank the editorial board of this journal, and particularly Prof. Eusebio Juaristi, for arranging this memorial issue dedicated to Ernest Eliel.

\section{References}

1. (a) Bailey, W. F.; Ovaska, T. V.; Leipert, T. K. Tetrahedron Lett. 1989, 30, 3901. (b) Bailey, W. F.; Ovaska, T. V. Tetrahedron Lett. $1990,31,627$.

2. Bailey, W. F.; Ovaska, T. V. J. Am. Chem. Soc. 1993, 115, 3080. 
3. (a) Barfield, M. J. Chem. Phys. 1964, 41, 3825. (b) Barfield, M. J. Am. Chem. Soc. 1971, 93, 1066.

4. Karplus, M. J. Chem. Phys. 1960, 33, 1842.

5. Sternhell, S. Q. Rev., Chem. Soc. 1969, 23, 236.

6. McConnell, H. M. J. Mol. Spectrosc. 1957, 1, 11.

7. (a) Barfield, M.; Spear, R. J.; Sternhell, S. Chem Rev. 1976, 76, 593. (b) Barfield, M. Magn. Reson. Chem. 2003, 41, 344.
8. Gaudemer, A. Stereochemistry, Fundamentals and Methods; Kagan, H. B., Ed.; Georg Thieme: Stuttgart, 1977; Vol. 1, p. 46 and references contained therein.

9. Burkert, U.; Allinger, N. L. Molecular Mechanics; ACS Monograph 177; American Chemical Society: Washington, DC, 1982.

10. Chem 3D Pro, CambridgeSoft Corporation, Cambridge, MA. 